\title{
Association of genotype of POU1F1 intron 1 with carcass characteristics in crossbred pigs
}

\author{
Gye-Woong Kim', Jae-Young Yoo ${ }^{2}$ and Hack-Youn Kim ${ }^{1 *}$
}

\begin{abstract}
This study was carried out to investigate the association of POU1F1 (POU domain, class 1, transcription factor 1, Pit1, renamed as POU1F1) gene with backfat thickness (mm), carcass weight (kg), pH, and color values $\left(\mathrm{L}^{*}, \mathrm{a}^{*}, \mathrm{~b}^{*}\right)$ in crossbred pigs (Landrace $x$ Yorkshire $x$ Duroc). Frequency of the AA genotype indel was at the highest level (66.67\%). Frequency of A allele (0.81) was higher than that of $\mathrm{b}$ allele (0.19). This population followed Hardy-Weinberg equilibrium. Carcass weights and $a^{*}$ values of the three genotypes were all significantly different $(p<0.05)$, respectively. However, backfat thickness, $L^{*}, b^{*}$, visual color, and $\mathrm{pH}$ of the three genotypes were not significantly different $(p>0.05)$. Visual color was negatively correlated with $L^{*}(r=-0.521)$ and $b^{*}(r=-0.390)$ values, $L^{*}$ value was correlated with $b^{*}(r=0.419)$ value, and $a^{*}$ value was positively correlated with $b^{*}(r=0.612)$ value. These results indicate that the POU1F1 gene affected carcass weight and meat redness.
\end{abstract}

Keywords: POU1F1, Carcass characteristics, Genotypes, Gene, Intron 1

\section{Background}

As of 2012, the annual average per capita meat consumption in Korea reached $40.6 \mathrm{~kg}$, with pork accounting for the highest average consumption at $19.0 \mathrm{~kg}$ [1]. The Food and Agriculture Organization (FAO) revealed that global consumption of pork underwent an annual increase of $2.1 \%$ from 1999 to 2010 [2]. Due to an increase in average income, consumers have developed a preference for high quality pork, and research has been conducted to select genetically superior traits in pork [3]. In Korea, a crossbreed of three pig breeds, Landrace, Yorkshire, and Duroc $(\mathrm{LY} \times \mathrm{D})$, has the largest market share based on its higher number of offspring, faster growth, and higher proportion of meat $[4,5]$ compared to other crossbreeds.

The POU1F1 (POU domain, class 1, transcription factor 1, Pit1) gene is expressed in the pituitary gland of pigs. It is associated with growth regulation as well as secretion of growth hormones, prolactin, and thyroprotein $\beta$-subunit [6,7]. POU1F1 is located on chromosome 13 and consists of six exons and five introns, and it has been shown to influence quantitative traits related to pig

\footnotetext{
* Correspondence: kimhy@kongju.ac.kr

'Department of Animal Resources, Kong-Ju National University, \# 54 Daehakro, Yesan, Chungnam 340-702, Korea

Full list of author information is available at the end of the article
}

growth [market weight, growth rate, and average daily gain (ADG)] as well as carcass traits (carcass weight, backfat thickness, amount of meat) [8-12]. Song et al. [13] reported that genetic change in intron 1 (insertion or deletion of $313 \mathrm{bp}$ ) of the POU1F1 gene is related to pig growth, and the genotype frequencies of intron 1 vary among breeds. Their analysis of 15 breeds, including 11 breeds of Chinese traditional varieties and four traditional breeds, confirmed $100 \%$ frequency of the BB genotype in Chinese traditional varieties of Tibetan, Lingao, Rongchang, Songliao Black, and Min. Frequencies of the BB genotype were high in the Meishan, Erhualian, Fenjing, and Leping Spotted breeds, although the highest genotypes were found to be $\mathrm{AA}$ type, $\mathrm{AB}$ type, and $\mathrm{BB}$ type in the Landrace, Pietrain, and Duroc breeds, respectively. Further, A allele was shown to be present at higher frequencies than B allele in all four breeds [13]. Previous studies have reported the relationship between POU1F1 gene intron region 3 and meat quality characteristics of the carcass [14] as well as that between daily gain and backfat thickness for the Landrace breed according to the POU1F1 genotype [15]. However, further accurate research is required on POU1F1 gene intron region 1 in crossbreeds of the three varieties.

Therefore, this study estimated POU1F1 genotype frequency in 168 crossbred pigs that were raised domestically 
in order to obtain basic data on meat quality assessment for the establishment of a high-quality pork production system by analyzing meat color and carcass characteristics.

\section{Methods}

Test animals

Standard laboratory animals used in this study included 168 crossbred pigs, with a live weight of approximately $110 \pm 5 \mathrm{~kg}$. The breeds were Landrace, Yorkshire, and Duroc (LYD or YLD) and were raised in Gyeonggi-do, Chungcheong-do, and Jeolla-do on Nong-Hyup animal feed, which meets the specifications of the National Research Council (NRC).

\section{Sampling and genomic DNA extraction}

To determine carcass grades and extract DNA, we transported animals to a slaughterhouse in Chungnam. After securing loin portions as laboratory samples, carcass grades were surveyed, and the meat was frozen and transported to the laboratory. The muscle tissues were then thawed at room temperature $\left(-25^{\circ} \mathrm{C}\right)$, and an appropriate amount was purified using a QIAamp Mini kit (QIAGEN ${ }^{\oplus}$, USA) following the manufacturer's protocol. Purified genomic DNA was dissolved in distilled water or TE buffer (Tris-EDTA, pH 8.0) and collected by centrifugation. The amount of genomic DNA was confirmed by performing electrophoresis, followed by storage at $-25^{\circ} \mathrm{C}$ until polymerase chain reaction (PCR) analysis.

\section{Genetic analysis}

The primers used for amplification of the POU1F1 gene are shown in Table 1. The primers used in the study were synthesized by the laboratory that amplified the intron 1 region of the POU1F1 gene. For the normal genotype (AA type), an amplified product of approximately 1,091 bp in size was obtained, whereas BB type amplified product was $778 \mathrm{bp}$. The synthesized primers were diluted to a final concentration of 10 pmol.

For the PCR mixture, prime Taq DNA polymerase from GeNet Biosystem (GeNet Bio. Co., Korea) was used. Each PCR mixture was $20 \mu \mathrm{L}$ and consisted of $1 \times$ buffer (0.01 M Tris- $\mathrm{HCl}, 0.05 \mathrm{M} \mathrm{KCl}, 0.08 \%$ nonidet), $1.5 \mathrm{mM}$ $\mathrm{MgCl}_{2}, 1 \mathrm{mM}$ of each dNTP, $10 \mathrm{pM}$ of primers, and $2.5 \mathrm{U}$

Table 1 Nucleotide sequences of primer pairs for PCR amplification of POU1F1 DNA fragment

\begin{tabular}{|c|c|c|}
\hline Name of primer & Sequence & Size of products \\
\hline POU1F1 gene in int & & 1091 or 778 bp \\
\hline \multicolumn{3}{|c|}{ Forward 5'-CAT TCC CAT TCT GCC ATT TG-3' (20 mer) } \\
\hline \multicolumn{3}{|c|}{ Reverse 5'-CCT GTT GCT GTG TTT CCC AG-3' (22 mer) } \\
\hline
\end{tabular}

of Taq. PCR conditions were as follows: pre-denaturation at $94^{\circ} \mathrm{C}$ for $5 \mathrm{~min}$, followed by 35 cycles of denaturation for $30 \mathrm{~s}$ at $94^{\circ} \mathrm{C}$, annealing for $1 \mathrm{~min}$ at $55^{\circ} \mathrm{C}$, and extension for $1 \mathrm{~min}$ at $72^{\circ} \mathrm{C}$. PCR was completed with a final extension for $5 \mathrm{~min}$ at $72^{\circ} \mathrm{C}$. The gene was amplified and analyzed using $1.5 \%$ agarose gel electrophoresis with TAE (40 mM Tris-acetate, $1.0 \mathrm{mM}$ EDTA) buffer. The quality of DNA was checked by adding $0.1 \mathrm{mg}$ of ethidium bromide to $1 \mu \mathrm{L}$ of electrophoresis buffer in the gel and the electrophoresis medium, followed by electrophoresis for approximately $20 \mathrm{~min}$ at $100 \mathrm{~V}$. A 100-bp ladder plus (MBI Fermentas Inc., USA) size marker was used as reference for the electrophoretic analysis, and images were obtained under UV illumination.

\section{Carcass trait according to genotype}

Backfat thickness, carcass weight, meat color, and $\mathrm{pH}$ were surveyed as carcass characteristics. For backfat thickness, grading data from the slaughterhouse were used, whereas weight after slaughtering was measured and used as the carcass weight of each pork sample (live weight, $110 \pm 5 \mathrm{~kg}$ ). For meat color, Hunter L" (lightness), $\mathrm{a}^{*}$ (redness), and $\mathrm{b}^{*}$ (yellowness) values on the cut surface of the fillet were measured using a color meter (Model NF333; Nippon Denshoku Co., Japan), and the standard meat color board at the time was $\mathrm{Y}=92.40$, $X=0.3136$, and $y=0.3196$. The visual color based on the meat color reference standard suggested by the National Pork Producers Council (NPPC) was directly compared for assessment based on seven steps, ranging from a light color score of 1 to a dark color score of 7 . The $\mathrm{pH}$ of muscle was measured using a glass electrode $\mathrm{pH}$ meter (340; Mettler Toledo, Switzerland) after mixing $5 \mathrm{~g}$ of sample with $20 \mathrm{~mL}$ of distilled water, followed by homogenization for $1 \mathrm{~min}$ at $8,000 \mathrm{rpm}$ using a homogenizer (Nissei, Model AM-7; Japan).

\section{Statistical analysis}

The gene and genotypes of POU1F1 intron 1 were analyzed using the SAS package (Statistical Analysis System, version 9.3). For intergroup genetic equilibrium, significance was tested using the $\chi^{2}$-test. After pigs were slaughtered, backfat thickness $(\mathrm{mm})$, carcass weight $(\mathrm{kg})$, meat color, and $\mathrm{pH}$ were determined to calculate the mean and standard deviations of each genotype, and correlation among carcass characteristics was calculated. For comparison of differences among groups, significance was tested at a $5 \%$ level by using Duncan's multiple-range tests.

\section{Results and discussion POU1F1 Intron 1 genetic analysis}

The results of PCR analysis of POU1F1 intron 1 are shown in Figure 1. The PCR-amplified products 


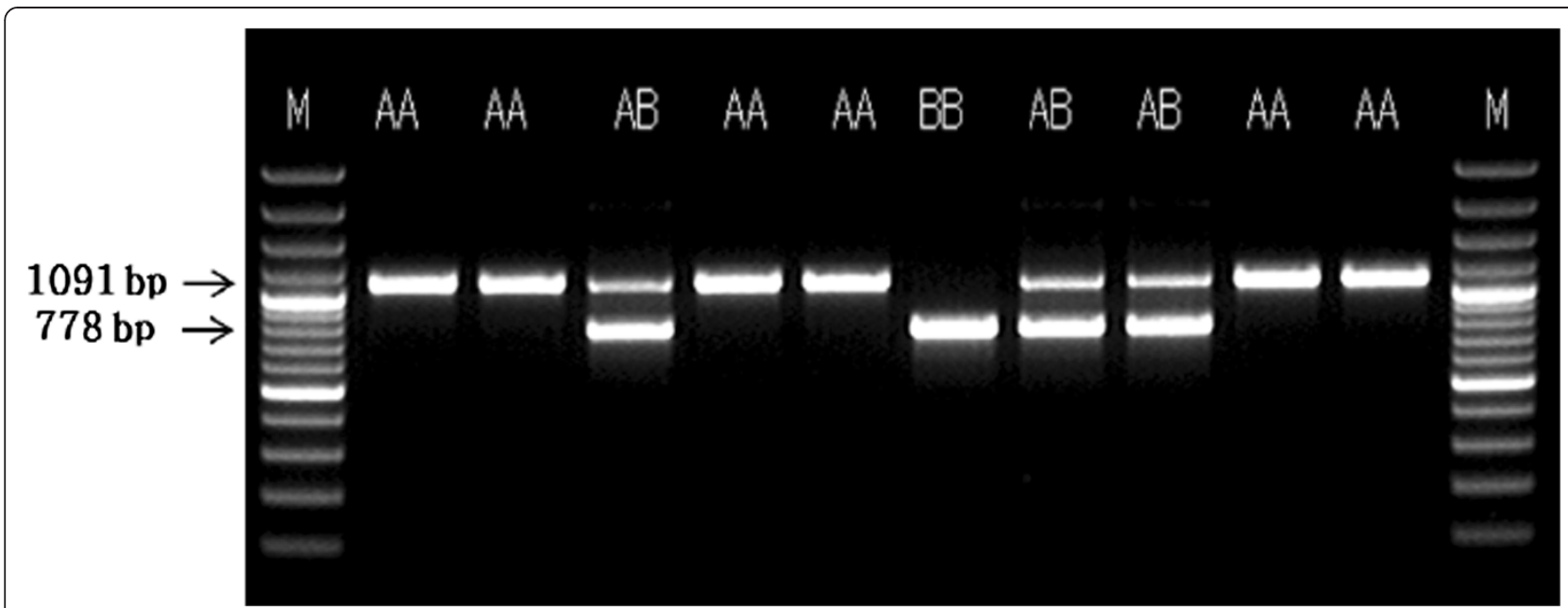

Figure 1 PCR products of POU1F1 gene intron 1 in pig samples. M: Molecular size standard (100-bp DNA ladder plus), lanes 2-11: PCR products. AA genotype: 1091 bp; AB genotype: 1091 bp and 778 bp; BB genotype: 778 bp.

consisted of three band types, namely $\mathrm{AA}$ and $\mathrm{BB}$ types as homozygotes and $\mathrm{AB}$ type as a heterozygote. Among these, AA type appeared as a single band of approximately $1091 \mathrm{bp}, \mathrm{AB}$ type appeared as two bands of 1091 and $778 \mathrm{bp}$, and BB type was a single band of $778 \mathrm{bp}$. These results are identical to those reported by Song et al. [13], who confirmed the presence of $A A, A B$, and $\mathrm{BB}$ types in intron 1 . On the other hand, a previous study identified AA, AG, and GG types in the FOU1F1 genotype of Korean beef [16].

The results of the analysis of the POU1F1 intron 1 SNP genotype and allele frequencies are shown in Table 2. The genotypes were categorized as homozygotes, namely AA and $\mathrm{BB}$ types, as well as heterozygotes, which is $\mathrm{AB}$ type, along with the existence of alleles $\mathrm{A}$ and $\mathrm{B}$. Of the 168 carcasses investigated, 112 were AA type, accounting for the highest percentage (66.67\%); 48 $(28.57 \%)$ and $8(4.76 \%)$ were AA and BB types, respectively. These results are similar to those of Song et al. [13], who showed that the Landrace breed is AA type (0.76). On the other hand, they contradict the genotype frequencies of the Yorkshire breed, which was shown to be $A B$ type (0.58), and Duroc breed, which was shown to be AA type (0.37). The discrepancies in these findings might be attributed to variations in gene distribution between crossbreeds and pure breeds, as crossbreeding involves changes in genotype frequencies. In contrast, the results of this study are similar to those of Franco et al. [15] and $\mathrm{Yu}$ et al. [17], who reported that the frequency of $\mathrm{AB}$ type is higher than that of $\mathrm{AA}$ type. Estimation of genotype frequencies revealed that $\mathrm{A}$ allele had a very high expression frequency (0.81), whereas $B$ allele had a very low frequency (0.19). Meanwhile, Franco et al. [15] reported expression frequencies of 0.88 and 0.12 for $\mathrm{A}$ and $\mathrm{B}$ types in the Landrace breed, respectively. On the other hand, Yu et al. [17] and Song et al. [13] demonstrated high expression frequencies for A allele in the Yorkshire, Duroc, Landrace, and Hampshire breeds, whereas the frequency of B allele was high in the Chinese Meishan breed. These results might be due to differences among each breed. The results of conformity determined on the basis of Hardy-Weinberg law were not

Table 2 Genotypic frequencies of POU1F1 gene and statistical test for Hardy-Weinberg equilibrium

\begin{tabular}{|c|c|c|c|c|c|}
\hline \multirow[t]{2}{*}{ Genotype } & \multirow[t]{2}{*}{ No. of pigs } & \multirow[t]{2}{*}{ Percentage (\%) } & \multicolumn{2}{|c|}{ Gene frequency } & \multirow[t]{2}{*}{ Statistical test } \\
\hline & & & A & B & \\
\hline AA & $112(110)$ & 66.67 & 0.810 & 0.190 & $x^{2}$-value $: 0.908^{N S} \mathrm{df}=1$ \\
\hline$A B$ & $48(52)$ & 28.57 & & & \\
\hline BB & $8(6)$ & 4.76 & & & \\
\hline Total & 168 (168) & 100 & & & - \\
\hline
\end{tabular}

NS: Not-significant $(p>0.05)$.

( ): No. of expected. 
Table 3 Association analysis among genotype of POU1F1 gene and carcass characteristics

\begin{tabular}{|c|c|c|c|c|c|}
\hline \multirow[t]{2}{*}{ Trait } & \multicolumn{4}{|c|}{ Genotype } & \multirow{2}{*}{$\begin{array}{c}\text { Significan } \\
\text { F-value }\end{array}$} \\
\hline & AA & $A B$ & BB & Mean \pm SD & \\
\hline Back fat Thickness (mm) & $13.09 \pm 0.92$ & $12.14 \pm 1.92$ & $13.33 \pm 1.86$ & $12.59 \pm 0.77$ & $0.107^{\mathrm{NS}}$ \\
\hline Carcass weight (kg) & $78.76 \pm 1.98^{b}$ & $92.00 \pm 7.61^{\mathrm{a}}$ & $92.33 \pm 14.68^{\mathrm{a}}$ & $81.86 \pm 2.26$ & $3.474^{*}$ \\
\hline$L^{*}$ & $39.54 \pm 0.91$ & $37.94 \pm 1.78$ & $38.11 \pm 3.56$ & $39.17 \pm 0.79$ & $0.343^{N S}$ \\
\hline$a^{*}$ & $17.42 \pm 0.53^{\mathrm{ab}}$ & $18.36 \pm 1.73^{\mathrm{a}}$ & $14.04 \pm 3.55^{b}$ & $17.30 \pm 0.52$ & $3.258^{*}$ \\
\hline$b^{*}$ & $10.87 \pm 0.40$ & $10.90 \pm 0.91$ & $9.78 \pm 1.92$ & $10.79 \pm 0.36$ & $0.327^{N S}$ \\
\hline $\mathrm{pH}$ & $5.70 \pm 0.62$ & $5.67 \pm 0.13$ & $5.59 \pm 0.05$ & $5.69 \pm 0.05$ & $0.195^{\mathrm{NS}}$ \\
\hline Visual color ${ }^{1)}$ & $4.05 \pm 0.17$ & $4.63 \pm 0.42$ & $5.00 \pm 0.07$ & $4.22 \pm 0.16$ & $2.102^{\mathrm{NS}}$ \\
\hline
\end{tabular}

${ }^{1)}: 1$ = pale, 7 = dark purple red.

$a, b$ : Means with different superscripts in the same column differ significantly $(p<0.05)$.

*: $p<0.05,{ }^{N S}$ : Not-significant.

significant $(\mathrm{p}>0.05)$, and this pork group was shown to maintain genetic equilibrium.

\section{Carcass characteristics according to POU1F1 Intron 1 genotype}

The results of the analysis of backfat thickness, carcass weight, Hunter L", a", and b"values, meat color (visual color), and $\mathrm{pH}$, which are the main carcass characteristics associated with the POU1F1 SNP genotypes $\mathrm{AA}, \mathrm{AB}$, and $\mathrm{BB}$, are shown in Table 3. The $\mathrm{AA}, \mathrm{AB}$, and $\mathrm{BB}$ genotype groups did not show intergroup significance, with an average backfat thickness of 12.14-13.33 mm ( $p>0.05)$. These results are similar to those of $\mathrm{Yu}$ et al. [17], who confirmed lack of significant differences among genetic groups for backfat thickness. For carcass weight, the AA genotype group showed a significantly lower weight $(78.76 \mathrm{~kg})$ compared to the $\mathrm{AB}(92.00 \mathrm{~kg})$ and $\mathrm{BB}$ $(92.33 \mathrm{~kg})$ types $(\mathrm{p}<0.05)$. These results are similar to those of $\mathrm{Yu}$ et al. [17], who reported that carcass weight is greater in $\mathrm{BB}$ type than in AA type and suggested that carcass weight can be influenced by $B$ allele.

No significant differences were observed in terms of meat color based on Hunter L" (lightness) and b" (yellowness) values, which were within the ranges of 37.94-39.54 and $9.78-10.90$, respectively $(\mathrm{p}>0.05)$. However, the POU1F1 intron 1 gene was found to affect color expression since Hunter $\mathrm{a}^{*}$ value (redness) was the highest in $\mathrm{AB}$ type pork $(p>0.05)$. In the meat color (visual color) assessment using the standard meat color board, the $\mathrm{AA}, \mathrm{AB}$, and $\mathrm{BB}$ genotypes showed values of 4.05, 4.63, and 5.00, respectively, with BB type showing a higher level of redness than AA type. In terms of $\mathrm{pH}$, average frequency was 5.69 for the $A B$ and $B B$ genotypes, although no significant differences were observed between them. This result is similar to the findings of $\mathrm{Yu}$ et al. [17], who reported no differences among the three genotypes in terms of meat color.

In terms of average carcass characteristics, Oh et al. [18] obtained different results, with an average backfat thickness of $27 \mathrm{~mm}$. Similarly, Choi et al. [19] reported

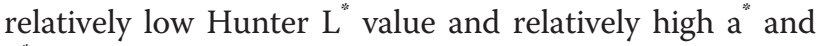
b" values in the crossbreeds. Results for $\mathrm{pH}$ values were within the range of 5.75-5.49, which is almost the same as that reported by Kim et al. [20] and Oh et al. [18], whereas Choi et al. [19] reported slightly higher $\mathrm{pH}$ values. These differences might be attributed to different pig raising methods such as feeding.

Table 4 Correlation coefficients among carcass characteristics in pigs

\begin{tabular}{|c|c|c|c|c|c|c|c|}
\hline Items & $x_{1}$ & $x_{2}$ & $x_{3}$ & $x_{4}$ & $x_{5}$ & $x_{6}$ & $x_{7}$ \\
\hline Back fat Thickness $\left(x_{1}\right)$ & - & 0.069 & 0.095 & 0.125 & -0.174 & 0.229 & 0.066 \\
\hline Carcass weight $\left(x_{2}\right)$ & & - & 0.101 & 0.099 & -0.216 & -0.090 & -0.0281 \\
\hline $\mathrm{pH}\left(\mathrm{x}_{3}\right)$ & & & - & 0.135 & -0.109 & 0.110 & -0.097 \\
\hline Visual color $\left(\mathrm{x}_{4}\right)$ & & & & - & $-0.521^{* * *}$ & 0.003 & $-0.390^{* *}$ \\
\hline$L^{*}\left(x_{5}\right)$ & & & & & - & -0.021 & $0.419^{*}$ \\
\hline$a^{*}\left(x_{6}\right)$ & & & & & & - & $0.612^{* * *}$ \\
\hline$b^{*}\left(x_{7}\right)$ & & & & & & & - \\
\hline
\end{tabular}




\section{Correlation between carcass characteristics}

The results of the correlation analysis of carcass characteristics are shown in Table 4. Meat color (visual color) showed a significant negative correlation with $\mathrm{L}^{\prime \prime}(\mathrm{r}=-0.52$, $\mathrm{p}<0.001)$ and $\mathrm{b}^{\prime \prime}(\mathrm{r}=-0.39, \mathrm{p}<0.01)$ values, whereas a low positive correlation was observed for backfat thickness, meat color $(r=0.12)$, and redness $(r=0.23)$. The $\mathrm{L}^{*}$ and $\mathrm{b}^{\prime \prime}$ $(\mathrm{r}=0.42, \mathrm{p}<0.05)$ values showed a low positive $(+)$ correlation, whereas a and $\mathrm{b}^{*}(\mathrm{r}=0.61, \mathrm{p}<0.001)$ values showed a very high positive correlation.

These results are similar to those of Kim et al. [21], who reported that color and yellowness as well as redness and yellowness show high correlations, whereas color and redness show a negative correlation. The results on correlations among meat color (visual color), color ( $\mathrm{L}^{*}$ value), redness ( $\mathrm{a}^{*}$ value), and yellow $\left(\mathrm{b}^{*}\right)$ values were very similar to those reported previously [22].

The results of this study suggest that changes in the POU1F1 intron region 1 are related to carcass weight, meat color, as well as growth. Further extensive study on the relationship between pig growth and changes in POU1F1 gene expression in relation to carcass characteristics is necessary in order to identify quantitative traits that might possibly be related to pig growth or meat quality of pork.

\section{Conclusion}

The results of the analyses of carcass characteristics according to POU1F1 genotypes of 168 domestically bred pig carcasses are as follows. Analysis of POU1F1 intron 1 genotypes showed that the AA genotype has the highest frequency (66.7\%), whereas frequencies of the $\mathrm{AB}$ and $\mathrm{BB}$ genotypes were $28.6 \%$ and $4.76 \%$, respectively. The A allele showed a very high expression frequency $(0.81)$, whereas $\mathrm{B}$ allele was estimated to have a low frequency (0.19). A $X^{2}$-test demonstrated that this allelic frequency was not in Hardy-Weinberg equilibrium. Backfat thickness and $\mathrm{pH}$ were not significantly different according to the genotype, but carcass weight was significantly higher in $\mathrm{AB}(92.00 \mathrm{~kg})$ and $\mathrm{BB}(92.33 \mathrm{~kg})$ types than in AA type $(78.76 \mathrm{~kg} ; \mathrm{p}<0.05)$. Further, Hunter a value was higher in $\mathrm{AB}$ type than in $\mathrm{BB}$ type $(\mathrm{p}<0.05)$. In addition, meat color (visual color) showed a negative correlation with L" (lightness) and $b^{\prime \prime}$ (yellowness) values. The results of this study showed that changes in the POU1F1 gene influence carcass weight, backfat thickness, and meat color. Therefore, extensive investigation of the relationship between carcass characteristics and changes in the POU1F1 gene is necessary to provide a reliable index for meat quality improvement.

\section{Competing interests}

The authors declare that they have no competing interests.

\section{Authors' contributions}

All authors participated in the design and laboratory work of the study. All authors helped to draft the manuscript, and all authors read and approved the final manuscript.

\section{Acknowledgments}

The authors would like to thank the farmers of Gyeonggi-do, Chungcheong-do, and Jeolla-do for their support during this study and for time spent during sampling and examination.

\section{Author details}

'Department of Animal Resources, Kong-Ju National University, \# 54 Daehakro, Yesan, Chungnam 340-702, Korea. ${ }^{2}$ Department of Obstetrics and Gynecology, Ewha Woman's University, Seoul 158-710, Korea.

Received: 23 September 2014 Accepted: 23 September 2014 Published: 27 November 2014

\section{References}

1. Ministry of Agriculture, Food and Rural Affairs (MAFRA): Information and Data of Agricultural Statistics of Korea. 2013. Available from http://www. mafra.go.kr/search/ totalSearch. jsp. Accessed May. 14.

2. FAO: Global Meat Mardets: Challenges. FAO Commodity and Trade Division. Brussels: FAO; 2003.

3. Kim GW: Analysis of carcass quality grades according to gender, backfat thickness and carcass weight in pigs. J Anim Sci Technol 2012, 54:29-33.

4. Hong KC, Kin BC, Son YS, Kom BK: Effects of the inating system on fattening performance and meat quality in commercial pigs. J Anim Sci Technol 2001, 43:139-148.

5. Jin SK, Kim IS, Hur SJ, Kim SJ, Jeong KJ: The influence of pig breeds on qualities of loin. J Anim Sci Technol 2006, 48:747-758.

6. Cohen LE, Wondisford FE, Radovick S: Role of pit-1 in the gene expression of growth hormone, prolactin and thyrotropin. Endocrinol Metab Clin North Am 1996, 25:523-540.

7. Hendriks-Stegeman BI, Augustijn KD, Bakker B, Holthuizen P, Vliet PC, Jansen $\mathrm{M}$ : Combined pituitary hormone deficiency caused by compound heterozygosity for two novel mutations in the POU domain of the Pit-1/ POU1F1 gene. J Clin Endocrinol Metab 2001, 86:1545-1550.

8. Brunsch C, Sternstein I, Reinecke P, Bieniek J: Analysis of associations of PIT1 genotypes with growth, meat quality and carcass composition traits in pigs. J Appl Genet 2002, 43:85-91.

9. Moody DE, Pomp D, Newman S, MacNeil M: Characterization of DNA polymorphisms in three populations of Hereford cattle and their associations with growth and maternal EPD in line 1 Herefords. J Anim Sci 1996, 74:1784-1793.

10. Renaville R, Gengler N, Vrech E, Prandi A, Massart S, Corradini C, Bertozzi C, Mortiaux F, Burny A, Portetelle D: PIT1 gene polymorphism, milk yield and conformation traits for Italian Holstein-Friesian bulls. J Dairy Sci 1997, 80:3431-3438

11. Stancekova K, Vasicek D, Peskovicova D, Bulla J, Kubed A: Effect of genetic variability of the porcine pituitary-specific transcription factor (PIT-1) on carcass traits in pigs. Anim Genet 1999, 30:313-315.

12. Yu TP, Wang L, Tuggle CK, Rothschild MF: Mapping genes for fatness and growth on pig chromosome 13: a search in the region close to the pig PIT1 gene. J Anim Breed Genet 1999, 116:269-280.

13. Song CY, Gao B, Teng S, Wang XY, Xie F, Chen G, Wang Z, Jing R, Mao J: Polymorphisms in intron 1 of the porcine POU1F1 gene. J Appl Genet 2007, 48(4):371-374.

14. Kim GW, Yoo JY: Analysis of carcass characteristics in the 3rd intron of pig POU1F1 gene. J Anim Sci Technol 2009, 51(4):283-288.

15. Franco MM, Antunes RC, Silva HD, Goular LR: Association of P1T1, GH and GHRH polymorphisms with performance and carcass traits in landrace pigs. J Appl Genet 2005, 46:195-200

16. Choi JR, Oh JD, Cho KJ, Lee JH, Kong HS, Lee HK: Identification and analysis of PIT1 polymorphisms and its association with growth and carcass traits in korea cattles (Hanwoo). J Emb Trans 2007, 22(3):167-172.

17. Yu TP, Tuggle CK, Schmitz CB, Rothschild MF: Association of PIT1 polymorphisms with growth and carcass traits in pigs. J Anim Sci 1995, 73:1282-1288 
18. Oh HS, Kim HY, Yang HS, Lee Jl, Joo YK, Kim CU: Comparison of meat quality characteristics between crossbreeds. Korean J Food Sci Ani Resour 2008, 28(2):171-180.

19. Choi YS, Park BY, Lee JM, Lee SK: Comparison of carcass and meat quality characteristics between Korean native black pigs and commercial crossbred pigs. Korean J Food Sci Ani Resour 2005, 25(3):322-327.

20. Kim IS, Jin SK, Song YM, Park KH, Kang SM, Ha JH, Kim IJ, Park YS, Kim JH: Quality characteristics of pork by sex on crossbred pigs. Korean J Intl Agri 2006, 18(1):34-39.

21. Kim GD, Jeong JY, Hur SJ, Yang HS, Jeon JT, Joo ST: The relationship between meat color(CIE L* and $\left.a^{*}\right)$, myoglobin content, and their influence on muscle fiber characteristics and pork quality. Korean J Food Sci Ani Resour 2010, 30(4):626-633.

22. Brewer MS, Zhu LG, Bidner BD, Meisinger J, McKeith FK: Measuring pork color: Effects of bloom time, muscle, $\mathrm{pH}$ and relationship to instrumental parameters. Meat Sci 2001, 57:169-176.

doi:10.1186/2055-0391-56-25

Cite this article as: Kim et al:: Association of genotype of POU1F1 intron 1 with carcass characteristics in crossbred pigs. Journal of Animal Science and Technology 2014 56:25.

\section{Submit your next manuscript to BioMed Central and take full advantage of:}

- Convenient online submission

- Thorough peer review

- No space constraints or color figure charges

- Immediate publication on acceptance

- Inclusion in PubMed, CAS, Scopus and Google Scholar

- Research which is freely available for redistribution 